\title{
Analysis of learning activities included in English text directed at students of Hospitality and Tourism
}

Análisis de actividades de aprendizaje incluidas en texto de inglés dirigido an estudiantes de Hotelería y Turismo

Análise de atividades de aprendizagem, incluindo texto em inglês voltado para estudantes de Hotelaria e Turismo

ARTICULO DE INVESTIGACIÓN

Johanna Pizarro Romero 1,2

jpizarro@utmachala.edu.ec

ORCID: 0000-0003-2515-4455

Jessenia Anabel Matamoros 1,2

jamatamoros@utmachala.edu.ec

ORCID: 0000-0003-2538-4832

\author{
Sara Vera Quiñonez ${ }^{1,2}$ \\ svera@utmachala.edu.ec
}

ORCID: 0000-0003-3633-9236

Kleber Oswaldo Sarmiento Chugcho 1

ksarmiento@utmachala.edu.ec

ORCID: 0000-0002-8178-3187

\section{1,2Universidad Técnica de Machala ${ }^{2}$ Miembro de grupo de investigación ELT Innovators}

Recibido 12 de noviembre 2020 | Arbitrado y aceptado 24 de noviembre 2020 | Publicado en diciembre 2020

\section{ABSTRACT}

English for Specific Purposes (IFE) textbooks are an important tool in the teaching-learning process of English. The purpose of this study was to identify the preferences of the learning activities included in an IFE textbook that the students of Hospitality and Tourism. The sample was 97 students. The survey was structured by abilities in listening comprehension, reading, writing, among others, for the analysis the LT-Lab software was applied divided into six groups according to their abilities. The results showed: group 1 the preferred learning activities: videos, web sources and songs; group 2, use of grammar, vocabulary, games, reading comprehension; group 3, role-playing games, dialogues, vocabulary and description; group 4, in the videos; group 5, readings and web sources, group 6, read, complete the sentences and crossword puzzles. In conclusion, the learning activity included in an ESP textbook preferred by the students were videos, web sources, songs, use of grammar, vocabulary, among others.

Palabras clave: Learning activities; special purpose books; skill development; teaching; languages

\section{RESUMEN}

Los libros de texto de inglés con Fines Específicos (IFE) son una herramienta importante en el proceso de enseñanza-aprendizaje del inglés. El propósito de este estudio fue identificar las preferencias de las actividades de aprendizaje incluidas en un libro de texto IFE que los estudiantes de Hotelería y Turismo. La muestra fue de 97 estudiantes. La encuesta fue estructurada por habilidades en comprensión auditiva, lectura, escritura, entre otras, para el análisis se aplicó el software LT-Lab dividido en seis grupos según sus habilidades. Los resultados demostraron: grupo 1 las actividades de aprendizaje preferida: videos, fuentes de webs y canciones; grupo 2, uso de la gramática, vocabulario, juegos, comprensión de lectura; grupo 3, juegos de rol, diálogos, vocabulario y descripción; grupo 4, en los videos; grupo 5, lecturas y fuentes web, grupo 6, leer, completar las frases y los crucigramas. En conclusión, la actividad de aprendizaje incluida en un libro de texto ESP preferido por los estudiantes fueron videos, fuentes web, canciones, uso de gramática, vocabulario, entre otras.

Key words: Actividades de aprendizaje; libros con fines específicos; desarrollo de habilidades; enseñanza, idiomas 


\section{RESUMO}

Os livros de inglês para fins específicos (IFE) são uma ferramenta importante no processo de ensinoaprendizagem de inglês. 0 objetivo deste estudo foi identificar as preferências das atividades de aprendizagem incluídas em um livro didático do IFE que os alunos de Hotelaria e Turismo. A amostra foi de 97 alunos. A pesquisa foi estruturada por habilidades de compreensão auditiva, leitura, escrita, entre outras, para a análise foi aplicado o software LT-Lab dividido em seis grupos de acordo com suas habilidades. Os resultados mostraram: grupo 1 as atividades de aprendizagem preferidas: vídeos, fontes da web e músicas; grupo 2, uso de gramática, vocabulário, jogos, compreensão de leitura; grupo 3, jogos de RPG, diálogos, vocabulário e descrição; grupo 4, nos vídeos; grupo 5, leituras e fontes da web, grupo 6, ler, completar as frases e palavras cruzadas. Em conclusão, a atividade de aprendizagem incluída em um livro didático de ESP preferida pelos alunos foram vídeos, fontes da web, músicas, uso da gramática, vocabulário, entre outros.

Palavras-chave: Atividades de aprendizagem; livros para fins específicos; Desenvolvimento de habilidades; ensino, línguas

\section{INTRODUCCIÓN}

The learning of technical English as a foreign language is a fundamental axis for university students. The use of this language allows obtaining more job opportunities. Many companies require staff with English language proficiency, technical English being of greater importance. The university has that great challenge of supporting its students to achieve proficiency in technical English (Pizarro, Chaves \& Farez, 2018). As for the academic, the students will have facilities to carry out their professional practices, including having the experience of visiting other countries. In addition, the knowledge of the language will allow venturing into the field of research and expand the knowledge, it is necessary to emphasize that there is a large percentage of publications in English (Pizarro, Matamoros \& Figueroa, 2018).

The process of teaching and learning English is the result of the reflective act that the teacher performs, which allows to make decisions to benefit the students, where the act of teaching and learning considers each of the members who participate in it. The reality of the classroom and is strengthened by the motivations, needs and individual ideas that are involved in this process (Díaz \& Jansson, 2011).

The problem question was posed by competencies, What are the learning activities included in the English for Specific Purposes textbooks preferred by students of the Hospitality and Tourism career?

This article presents the results of a survey made to the students of the hotel and tourism career, participated several levels. The objective of this research is to determine the characteristics that technical English books should possess. Then, general aspects and criteria of several authors on the texts for the teaching of English will be addressed.

\section{Literature review}

The quality is considered an important aspect of education to others elements such us classroom, teachers, resources, materials, textbooks in general and Foreign Language (EFL) textbooks in particular have always been items which all together play a remarkable role in the quality of education (Alharbi, 2015).

To Siegel (2014) a good choice of texts is always a concern when selecting the right book for teaching English. For teachers, it is not an easy job because the lack of knowledge can lead to choose a book for many reasons; the factors could be: price, the number of activities, or just which is more attractive to the view, and taking apart the most important use, being the target public. There are many items that the teachers must evaluate now of selection. 
However, the decision making of the teacher to guarantee the quality of a book does not guarantee the best work in the teaching - learning process of English. According to Sari, Ülgü, \& Ünal (2009) the combination of textbooks could turn into excellent resources that allow the development of learning. Besides, a textbook most of the time always introduces weak and strong activities when the objective is to develop all skills of the language at the same time and should involve the students in a real context of the target language. (Mishan, 2005).

The textbooks represent a connection among teacher, student and reality (Madrid 2001). Besides, to McDonough (2010) a teaching English textbook should connect the students to a new culture. Hence, the ELT textbooks are a support that stimulates the student's cognitive processes to interact with English (Wallace, 2005), among other considerations also allows the student to discover aspects of the language. Therefore, the goal of a elt textbook is to remarkable the best of that culture, and focusing the target language naturally (Siegel, 2014).

According to Hutchinson, Waters (1998) \& Cunningsworth (1995), the teaching materials are resources clear and coherent guide that provide practical exercises, attractive visual resources that encourage the student and ensure the acquisition and development of English skills, preparing them for the process Learning. Based on these considerations, the role of didactic texts is to provide language information to be practiced interactively (Tomlinson, 2012).

In the educational field, there are a wide number of practical problems due to lack of textbook guidance and extracurricular activities, the domination of traditional instructional methods, and the culture of resistance to change (Sheldon, 1988). To establish the impact of teaching materials on students which uses them, teachers follow their personal impressions instead of focusing their purpose and what is required of the learner (Tomlinson, 2003).

On the other hand, Wallace (2005), Hutchinson \& Waters (1987), mention distinction and considers the textbook evaluation as an interactive process that includes an objective and subjective analysis of the materials. It adds to its definition the correspondence that must exist between teaching materials and the needs of students and teachers in a particular context (Mohammadi \& Abdi, 2014). In view of that the didactic textbooks that are used for the teaching-learning process of english, the standards of teachers consider for the selection of materials is questioned (Sheldon, 1988).

It is important to emphasize the importance of interaction as a means and final objective in language learning. Being the teaching methodology of English now communicative, experts emphasize the use of authentic didactic resources and chords to the current methodology (Nieto, 2002). Teachers often lack enough time and administrative support to create or adapt resources needed for their classes. To invest time to design a book tailor to their needs but the analysis of target public is imperative to provide just the students require (Soori, 2011).

Another challenge for teachers could be the costs and time of dedication due to the number of hours in public rather in private schools for the teaching (Cunningsworth, 1984). There is a lack of knowledge about the criteria for evaluating texts and, therefore, we have not relied on what to base our judgments on, how to qualify our decisions and how to report the results of our 
evaluation (Ansary and Babaii 2002). The selection of textbooks has been done in a hurried way and with a lack of systematically applied criteria. There are contributions from researchers (Sheldon, 1988) who have offered methods to evaluate in detail and help teachers to be more objective.

Three types of material evaluation, determining an initial or diagnostic phase which examines the potential performance of a textbook, a second phase that is to verify the material currently being used and the third phase that determines future or future use (Cunningsworth, 1995). According to Prabhu (1987) textbooks are materials that are perfectly designed and designed to provide uniformity with respect to the differences that exist in students and teaching methodologies used by teachers.

The EFl textbooks for the teaching of English represents a professional, financial and educational investment. In this sense, only a precise evaluation under the criteria of selection of a large number of books on the market, will enable the teacher to work effectively in the classroom (McGrath, 2013). According to Verboord \& Rees (2009) the analysis of the content of the textbooks according to the international standards of English and the management that the teachers do of them. On the other hand, Verboord \& Rees, (2009) points out that the need for strategic planning, reflection and evaluation is completely ignored.

\section{Perceptions for technical english textbook}

Active learning is usually given by games, student response system or lectures. (Prince, 2004). For example, during lectures students requires processing information consciously and interacting among them. When students have the chance to participate in conferences are generally more motivated and confident in using their new knowledge and more valuable learning experience (Miller, Wilson, Miller, \& Enomoto, 2017). According to Biggs (2011) the students can raise their level of autonomy, also be more critical and more creative thinker with "higher levels of thinking and knowledge application."

To promote active learning stimulates the students' interest (Bartram \& Bailey, 2009). Slate, LaPrairie, Schulte, \& Onwuegbuzie (2009) explains the use of humour, which can be an effective engagement strategy that can enhance learning (Garner, 2006). Other positive aspect of humour is disappear the individualism (Zhang 2005, p. 118). It is important to handle the humour appropriately and in such a way that students feel more comfortable in classroom, and helps to decrease the level of anxiety, for students is difficult to control their nervous at the moment to participate among them (Wagner \& Urios-Aparisi, 2011, p. 401).

Humour plays a role in promoting students to increase their interest in order to become more receptive to learn actively. According to Nesi (2012) there are three categories commonly used to describe humour: superiority (where one person is at an advantage over another); incongruity; and relief (where tension is built and then resolved) (p. 80). The first one is not always desirable in a learning situation; the students might feel uncomfortable by their teacher or peers.

To Alhamlan (2013) the tasks to increase the number of new vocabulary in the textbook is important. The number of words define the scope and depth of understanding. Having a rich vocabulary in English especially in the professional area is essential to master the language. Therefore, acquiring new vocabulary will help to improve the oral expression and comprehension skills. 
The process of learning and memorizing words must be constant; otherwise, the words we learn and do not use are forgotten. It is recommended a daily practice of 5 new minimum words each day. The use of images is effective because the teacher does not need to explain the meaning in Spanish, in this case the learning is by relationship. Making use of the benefits of technological tools generates a dynamic interaction in the student, for example, blogs, podcasts, websites or platforms. In addition, the use of crosswords, alphabet soup, are activities that help concentration.

Another important point is to teach the useful vocabulary (Perry, 1969). It is something so basic that it seems unnecessary, but sometimes we try to learn a large amount of vocabulary that maybe we will not use for now or ever. Therefore, it is better to focus, at first, on learning the most basic and necessary to relate to other people, use it for a specific job, travel, among other aspects (Palumbo, Kramer-Vida, \& Hunt, 2015). This does not mean that acquiring more knowledge is something negative, but when we start studying a language, it is important to go little by little, with patience, because later we will increase the vocabulary and, with this, possibly also the difficulty of learned (Kalyuga \& Kalyuga, 2008).

\section{Materials and Methods}

This research presented a descriptive qualitative design in order to know the preference that the students of the Hospitality and Tourism career in a public university in Machala had with respect to the learning activities that a textbook had for teaching English with specific purposes (ESP) according to their own needs and experiences using the book. The total population surveyed was 97 students. The age range of the students was 17 to 25 years. The surveys were randomly distributed by skills: 14 for writing, 19 for listening, 16 for grammar, 16 for speaking, 17 for vocabulary and 17 for reading; For the content analysis, the T-lab software was applied. Each group represents the learning activities of preference, without preference or suggested by skills, group 1 represents listening, group 2 is reading, group 3 is speech, group 4 is writing, group 5 is grammar and group 6 is vocabulary.

\section{RESULTS AND DISCUSSION}

The clusters represent (Table 1) the skills, being cluster 1 listening, cluster 2 reading, cluster 3 speaking, cluster is writing, cluster is grammar and cluster 6 vocabulary. Each cluster has a group of slogans or keywords. The third column details the number of time the slogans repeated in the surveys. The most remarkable slogans required by the students of hotel and tourism career are: videos, songs, readings, role playing, dialogues and fill in the blanks. There are more slogans which will be included analyzed during the discussion. 
Table 1. Group representing preferred learning activities

\begin{tabular}{|c|c|c|}
\hline CLUSTERS & KEYWORDS & $\begin{array}{l}\text { KEYWORDS REPEATED IN THE } \\
\text { CLUSTER }\end{array}$ \\
\hline \multirow{7}{*}{ CLUSTER 1} & videos & 66 \\
\hline & fill in the blanks & 46 \\
\hline & web sources & 31 \\
\hline & questioning & 4 \\
\hline & weekly videos log & 8 \\
\hline & texts & 4 \\
\hline & songs & 23 \\
\hline \multirow{4}{*}{ CLUSTER 2} & grammar & 52 \\
\hline & Vocabul ary & 23 \\
\hline & games & 20 \\
\hline & lyrics & 4 \\
\hline \multirow{7}{*}{ CLUSTER 3} & reading comprehension & 55 \\
\hline & role play & 45 \\
\hline & describing & 15 \\
\hline & dialogues & 44 \\
\hline & vocabulary & 23 \\
\hline & topics & 4 \\
\hline & conversations & 5 \\
\hline \multirow{3}{*}{ CLUSTER 4} & summaries & 4 \\
\hline & stories & 9 \\
\hline & describing & 15 \\
\hline
\end{tabular}




\begin{tabular}{|c|c|c|}
\hline \multirow{6}{*}{ CLUSTER 5} & videos & 66 \\
\hline & games & 20 \\
\hline & readings & 53 \\
\hline & web sources & 30 \\
\hline & sentences & 26 \\
\hline & dialogues & 22 \\
\hline \multirow{4}{*}{ CLUSTER 6} & reading & 53 \\
\hline & complete the sentences & 26 \\
\hline & describing & 15 \\
\hline & crosswords & 26 \\
\hline
\end{tabular}

The clusters represent the skills, being cluster 1 listening, cluster 2 reading, cluster 3 speaking, cluster is writing, cluster is grammar and cluster 6 vocabulary. Each cluster has a group of slogans or keywords. The third column details the number of time the slogans repeated in the surveys. The most remarkable slogans required by the students of hotel and tourism career are: videos, songs, readings, role playing, dialogues and fill in the blanks. There are more slogans which will be included analyzed during the discussion.

\section{Videos}

Listening is one of the four english language skills. Studies confirm the importance of audio visual resources (Unal \& Sever, 2017). Nowadays, technology allows using tools such as message or listen to messages (Topcuoglu 2011), with this hearing is not just listening. Seeing shows an effective element (Yildiz 2006). According to Tuzel (2010) the skill to construct conscious visual messages and to produce meaning from visual messages in the communication process. Studies indicate that visual resources play an important role in learning, reconstruction and understanding of knowledge.

The use of video in the classrooms for teaching purposes is an interesting topic due to the impact in this century as a means of communication. One characteristic of the image is that it does not depend in essence on reading to convey a meaning or the video does not essentially depend on the reading to capture a meaning. The video has special features that make it unique, the combination of the moving image with the sound, make its presentation attractive. The videos is one of the most requested by the students surveyed. They consider that this resource is more effective to learn technical English, awakens interest and helps them to assimilate the technical vocabulary more quickly. Also, for learning grammar. Therefore, they suggest finding more videos in the English text. 


\section{Fill in the blanks}

Another characteristic with a high range is fill in the blanks. According to Gang Xu (2014) state that students use a five-step strategy to learn new words: 1 . they see a new word in some source text, 2 . form a clear visual or aural image of the form of the word, 3. learn the meaning of the word, 4. develop a memory connection between the form and meaning of the word, and 5. use the word. Fill-in the blanks activities can show the English definition of a word or phrase and the students have to type in the word that goes with the definition. This activity encouraging to the students to guess the correct word according to the context (Perry, 1969).

\section{Songs}

The use of songs for learning English has a positive effect on the student as a playful, creative and fun activity. In general, all songs are written with a purpose and their content is planned in order to attract the attention of the public. The use of the songs makes the student get involved with the language. In addition, it increases the vocabulary and new expressions of the language (Baleghizadeh \& Nasrollahi Shahri, 2014). On the other hand, you should also talk about some inconveniences that can occur in the classroom working with songs. It is of great value to look at the behavior of the student since he can misinterpret the situation thinking that there is no established goal and that the class is just a hobby. A more suitable way to work with songs is to put the students in context, either with drawings or any other help, listen to the song and have the students repeat to achieve a good pronunciation, develop the proposed activities whether they are guides or workshops, individually and as a team and without a doubt sing the song (Chou, 2014).

Taboada Ana \& Buehl Michelle M. (2012)

the development of reading pursues a functional approach in the learning of the language. It is important to incorporate content that addresses both the use and reflection on the language, aimed at developing students' comprehensive and expressive abilities. Comprehensive reading allows the reader to interpret the entire contents of the text (Assaf, 2008). Where also acquired knowledge of grammar and vocabulary immersed. The grammatical contents should research in the application and control of the comprehension strategies, which forces to center the grammatical reflection in three areas: contextual, textual and sentences (Gang Xu, 2014).

To extend the grammatical reflection to these three areas implies to stop at the appropriate construction of a text. The relationship of this skill is very close to the cluster 4 and 5 . The cohesion that exists between them is close. The development of reading is not done in isolation, it is connected to developing the ability to write, summarize, describe, and identify primary and secondary ideas. The grammar of the text as such does not manifest itself independent of the disciplines that occupy minor linguistic units such as morphology, syntax, phonology, lexicology, semantics), but necessarily part of them and the relationship of the verb tenses (Fisher, 2001).

The student now of communicating takes words that combined according to some rules creates sentences. These sentences do not follow each other in a disorderly way, but are obeying a series of rules, which make it possible for the message configured by the sender to the text. The fact that the message belongs to oral or written communication implies that according to its modality, it also has its own rules.

In this case, by focusing on research in technical English, the readings involve students to better understand the culture (Palumbo, 2015). The language is a true reflection of the 
values and customs of the communities of speakers. Therefore, if the student develops reading comprehension, he or she will improve knowledge about the culture of the language (Pinto da Silva, 2004). Therefore, it helps to assimilate technical vocabulary and idiomatic phrases. English has phrases difficult to understand for non-native speakers. Through the practice of reading, the student will memorize the most used words and understand them in context.

\section{Role playing}

According to the surveys, the role-play was one of the characteristics that was present in most clusters. This activity allows you to simulate real life situations. It generates practical learning to develop the student's communication skills. Precisely, the Role Playing, each participant plays a role and must think, act and decide how his character would. In technical English teaching, this activity provides a practical approach.

Fisher (2001) the advantages of Role Playing are several, such as: 1) It promotes an environment of interest and study around the discussion of a problem. It is a motivating and participatory technique through dialogue or later debate, especially when the group feels involved in what it represents. 2) Identify the students with the problem dealt with and encourage reflection on the attitudes that are involved in it. Role Playing allows to deepen the different aspects of a problem through a more dynamic and interactive methodology than the conventional lesson. 3) It is an ideal method to develop abilities of teamwork and decisionmaking, creativity and solution of transversal problems in group functioning. 4) It allows you to go down from the field of abstractions to that of realities and to make participants aware of the need to learn. 5) Stimulates the creative and imaginative potential of the person because they must imagine how their character would think and act.

\section{Dialogues}

The lema dialogue is in the cluster speaking. To Luoma (2009) oral production is one of the four linguistic skills involved in the development of communicative competence. Generally, it is one of the most complex because the student in a very short space of time has to think about what he is going to say, how to say it, say it clearly and without making grammatical or pronunciation mistakes. Without leaving aside, the insecurity that usually has to communicate in another language. Additionally, one of the difficulties lies in not only knowing the grammar but also having a wide vocabulary, depending on the situation and the people to whom the speaker is addressing.

In general, the most common problems that arise in terms of oral production are often of a linguistic and / or psychological nature. On the other hand, (Stewart, 1980) state that some of the linguistic difficulties that students have during a communicative event are: speaking at a slow pace, taking many breaks, using too many phrases, delaying organizing the ideas, expressing incomplete sentences, not joining ideas in an organized and coherent way, making grammatical errors regularly, lacking the necessary vocabulary to communicate, not using reduced forms of the language such as contractions, elicitations and syllabic reductions, and not correctly pronouncing words with an adequate intonation.

On the other hand, regarding problems of psychological order, Moyles, Adams, \& Musgrove (2002) states that one of the factors that negatively affect oral production in students is the fear of making mistakes in front of their classmates and teachers. It could due to the lack of an atmosphere of confidence in the 
classroom or the use of inadequate correction techniques by teachers. Additionally, Den Otter \& Emmitt (2008) points out that the most common psychological problems in learning a foreign language are anxiety, insecurity, fear and shame when facing communicative situations.

\section{CONCLUSIONS}

This study reveals that the students' learning activities included in ESP textbooks of the Hotel and Tourism career preferences were videos, web sources, songs, use of grammar, vocabulary, games, reading comprehension, role play, dialogues, describing, complete the sentences, and crosswords; the learning activities they prefered by skills were; In listening: videos, fill in the blanks, web sources, questioning, weekly video logs, texts, and songs; in reading: use of grammar, vocabulary, and games, and lyrics; in speaking: reading comprehension, role play, describing, dialogues, vocabulary, topics, conversations; in writing: describing, summaries, describing; in grammar: videos, games, readings, web sources, sentences, and dialogues and in vocabulary, reading, complete the sentences, describing, and crosswords.

\section{REFERENCES}

Ansary, H. \& Babaii, E. (2002). Universal characteristics of EFL/ESL textbooks: A step towards systematic textbook evaluation. The Internet TESL Journal, 8(2), available on-line textbooks/

Alharbi, A. (2015). CURRICULUM \& TEACHING STUDIES | RESEARCH ARTICLE A descriptive-evaluative study of a Saudi EFL textbook series. Cogent Education, 1(1), 126.

https://doi.org/10.1080/2331186X.2015.1 079946

Assaf, L. C. (2008). Professional identity of a reading teacher: Responding to high-stakes testing pressures. Teachers and Teaching: Theory and Practice, 14(3), 239-252. https://doi.org/10.1080/13540600802006 137

Baleghizadeh, S., \& Nasrollahi Shahri, M. N. (2014). EFL teachers' conceptions of speaking competence in English. Teachers and Teaching: Theory and Practice, 20(6), 738-754.

https://doi.org/10.1080/13540602.2014.8 85702

Chou, M. hsuan. (2014). Assessing English vocabulary and enhancing young English as a Foreign Language (EFL) learners' motivation through games, songs, and stories. Education 3-13, 42(3), 284-297. https://doi.org/10.1080/03004279.2012.6 80899

Cunningsworth, A. (1995). Choosing your coursebook. Macmillan

Cunningsworth, A. (1984). Evaluating and selecting EFL teaching materials. London: Heinemann Educational Books Ltd, (chapter 8), 62. https://doi.org/10.1016/0346251X(86)90057-6

Den Otter, A., \& Emmitt, S. (2008). Design team communication and design task complexity: The preference for dialogues. Architectural Engineering and Design Management, 4(2), 121-129. https://doi.org/10.3763/aedm.2008.0072

Fisher, R. (2001). Analysing the role of the teacher in early reading: A lesson for researchers. Teachers and Teaching: Theory and Practice, 7(3), 297-313. https://doi.org/10.1080/13540600120078 229

Gang Xu. (2014). A Study on English Vocabulary Learning Strategies Used by Chinese College Students. Studies in Literature and Language, $\quad 9(1)$, 111-116. https://doi.org/10.3968/5397

Kalyuga, M., \& Kalyuga, S. (2008). Metaphor awareness in teaching vocabulary. Language Learning Journal, 36(2), 249-257. https://doi.org/10.1080/09571730802390 767

McDonough, J. (2010). English for specific purposes: A survey review of current materials. ELT Journal, 64(4), 462-477. 
https://doi.org/10.1093/elt/ccq060

McGrath, I. (2013). English Language Teaching Materials: Theory and Practice. ELT Journal, 67(1), https://doi.org/10.1093/elt/ccs072

Miller, J. L., Wilson, K., Miller, J., \& Enomoto, K. (2017). Humorous materials to enhance active learning. Higher Education Research and Development, 36(4), 791-806. https://doi.org/10.1080/07294360.2016.1 238883

Mohammadi, M., \& Abdi, H. (2014). Textbook Evaluation: A Case Study. Procedia - Social and Behavioral Sciences, 98, 1148-1155. https://doi.org/10.1016/j.sbspro.2014.03.5 28

Moyles, J., Adams, S., \& Musgrove, A. (2002). Using Reflective Dialogues as a Tool for Engaging with Challenges of Defining Effective Pedagogy. Early Child Development and Care, 172(5), 463-478. https://doi.org/10.1080/03004430214551

Palumbo, A., Kramer-Vida, L., \& Hunt, C. V. (2015). Teaching vocabulary and morphology in intermediate grades. Preventing School Failure, 59(2), 109-115. https://doi.org/10.1080/1045988X.2013.8 50649

Perry, L. D. (1969). Teaching Vocabulary to Slow Learners. The Clearing House: A Journal of Educational Strategies, Issues and Ideas, 44(3), 164-165. https://doi.org/10.1080/00098655.1969.1 1478359

Pinto da Silva, C. (2004). Teachers and Learners: Investigating the Language Classroom.

Pizarro, J. Chaves, A., \& Mirian, F. (2018). CAPÍTULO VI El Apoyo de las TIC's y el Idioma Inglés. In Exportations (p. 25)

Prabhu, N. S. (1987). Second language pedagogy (Vol. 20)

Sari, İ., Ülgü, S., \& Ünal, S. (2009). Materials Evaluation and Development: Syllabus, Setting and Learner Needs. International Journal of Teaching and Education, $I I(2), 60-65$
Sheldon, L. E. (1988). Evaluating ELT textbooks and materials. ELT Journal, 42(4), 237-246. https://doi.org/10.1093/elt/42.4.237

Siegel, A. (2014). What should we talk about? The authenticity of textbook topics. ELT Journal, 68(4), 363-375. https://doi.org/10.1093/elt/ccu012

Stewart, 0. (1980). Communicating with dialogues. Ergonomics, 23(9), 909-919. https://doi.org/10.1080/00140138008924 800

Taboada Ana, \& Buehl Michelle M. (2012). Teachers' Conceptions of Reading Comprehension and Motivation to Read. Teachers and Teaching: Theory and Practice, 18(1), 101-122. Retrieved from http://search.proquest.com/docview/1018 482527? accountid=14744

http://VS4EE7HH3A.search.serialssolutions .com/directLink?\&atitle=Teachers $\% 27+$ Con ceptions+of+Reading+Comprehension+and +Motivation+to+Read\&author=Taboada $\% 2$ C+Ana\%3BBuehl\%2C+Michelle+M.\&issn=1 35406

Tomlinson, B. (2012). Materials development for language learning and teaching. Language Teaching, 45(02), 143-179. https://doi.org/10.1017/S0261444811000 528

Unal, F. T., \& Sever, A. (2017). Effect of Nature Visuals on Listening Skills. International Journal of Educational Sciences, 5(3), 195200.

https://doi.org/10.1080/09751122.2013.1 1890078

Verboord, M., \& van Rees, K. (2009). Literary education curriculum and institutional contexts. Textbook content and teachers' textbook usage in Dutch literary education, 1968-2000. Poetics, 37(1), 74-97. https://doi.org/10.1016/j.poetic.2008.08.0 01

Wallace, C. (2005). International Perspective on Materials in ELT. ELT Journal, 59(July), 258259. https://doi.org/10.1093/elt/cci048 